attention each day. Surveys of air pollution in regions of a few square miles can be made by the lead peroxide method. The booklet also describes another kind of survey, which has perhaps been neglected because it depends on the ability to foretell $24 \mathrm{hr}$. or more of dry, calm weather. This involves the exposure of Petri dishes on pre-selected sites, and the subsequent weighing to the nearest $0.1 \mathrm{mgm}$. of the solid matter deposited in them.

\section{Resistance Thermometry near the Absolute Zero}

Is recent years certain commercial carbon resistances have become increasingly important as sensitive and compact resistance thermometers for the temperature range within a few degrees of the absolute zero. They suffer, however, from the disadvantage that warming to room temperature causes their subsequent low-temperature properties to be markedly different, so that recalibration is necessary. It is now claimed by J. E. Kunzler, T. H. Geballe and G. W. Hull, of the Bell Telephone Laboratories, that germanium suitably doped with arsenic forms a sensitive and stable resistance thermometer, maintaining its calibration within a fow ten-thousandths of a degree over many cycles of warming and cooling. No examples are available commercially as yet, but if it should prove possible to market reliable germanium thermometers at a reasonable price, they will be welcomed by all who perform precise thermal measurements at very low temperatures.

\section{The Great Northern Route}

V. F. Burkhanov (Priroda (1), 9; 1957) gives a brief history of the progress in the establishment of the "Great Northern Route" in the U.S.S.R. from the penetration of the Russian sailings on the White Sea in the ninth century, through the numerous explorations and scientific expeditions of the seventeenth and later centuries to the modern regular navigational service with its supporting new ports, river stations and an aerial network.

\section{Electronics Convention}

THE thirteenth annual Electronics Exhibition and Convention, organized by the Northern Division of the Institution of Electronics, will be held during the periods July 10-12 and 14-16 at the Manchester College of Science and Technology. The Exhibition will consist of a manufacturers' section and a scientific and industrial research section, including exhibits of interest to all branches of science and industry. The Convention will include a series of lectures and film-shows on electronic topics. Admission will be free of charge. Further information can be obtained from the honorary exhibition organizer, Mr. W. Birtwistle, 78 Shaw Road, Rochdale, Lancs.

\section{World Power Conference}

Tew theme of the Canadian Sectional Meeting of the World Power Conference, to be held in Montreal during September 7-11, 1958, will be "Economic Trends in the Production, Transportation and Utilization of Fuel and Energy". Arrangements have been made by the Papers Committeo (chairman, Sir Josiah Eccles, deputy chairman of the Electricity Council) for the preparation of sixteen papers for presentation by the British National Committeo. The programme, with membership and other application forms, can be obtained from the Secretary, British National Committee, World Power Conference,
201 Grand Buildings, Trafalgar Square, London, W.C.2.

At the meeting of the International Executive Council of the World Power Conference held in Belgrade in June 1957, Bulgaria and Colombia were elected members, thus increasing the membership to fifty-two countries and territories. Major General H. A. Young, Deputy Minister of Public Works and chairman, Canadian National Committoe of the World Power Conference, was elected a vice-chairman of the International Executive Council in succession to Dr. A. J. Alves de Souza, of Brazil, whose term of office had expired. The invitation of the Spanish National Committee for a Sectional Meeting of the World Power Conference to be held in Madrid in 1960 has been accepted. The sixth plenary meeting of the World Power Conference will be held in Australia in 1962, and a Sectional Meeting will take place in Switzerland in 1964.

\section{Index of Films on Chemistry}

THE Royal Institute of Chemistry is preparing an index of films on chemistry, and would welcome details of any professional or amateur film that is available on loan or for hire but is not listed in the general film catalogues. Material for this index is being collected by Dr. J. H. Pryor, 3 Forsyte Crescent, Upper Norwood, London, S.E.19, to whom relevant information should be sent. The perticulars required are: The title, the length, the sponsor and distributor, whether black and white or colour, whether $16 \mathrm{~mm}$. or $35 \mathrm{~mm}$., whether available on free loan or for hire, a brief account of the contents of the film, and the audience for which it would be suitable.

\section{The Plastics Industry Education Fund}

THe Plastics Industry Education Fund was estab. lished in 1952 and the Trustees heve now published their second Progress Report covering the years 1955-57 (Pp. 11. London: The Plastics Institute, 1958). The income of the Fund during this period was approximately $£ 15,000$. More than half this amount has been spent in providing training grants for students from the plastics industry to study full time at universities and technical colleges; bursaries and scholarships for boys and girls on loaving school to study full time for qualifications of the Plastics Institute or for the Diploma in Technology; a research studentship ; a travel scholarship, and grants for the purchase of capital equipment at various technical colleges.

The rest of the income has been used for the publication of six monographs on plastics technology for students, on buying library books for technical colleges, on printing careers literature and on a display case on plastics at the Science Museum. Almost all the students helped by the Fund are now working in the plastics industry, and the Trustees contemplate increased expenditure on scholarships now that approvel has been given by the National Council for Technical Awards for sandwich courses in plastics technology at the Birmingham College of Technology, the Borough Polytechnic and the Brunel College of Technology, Acton. Much interest is shown by students in the production of plastics materials, but a flow of technicians to the processing sides of the plastics industry is highly desirable and it is suggested that moulding, fabricating and plastics engineering firms should encourage promising per. sonnel to broaden their technological background by the study facilities afforded by the Fund. 